\title{
Mosquitoes of North-Western Europe as Potential Vectors of Arboviruses: A Review
}

\author{
Jean-Philippe Martinet ${ }^{1,2}, * \mathbb{D}$, Hubert Ferté ${ }^{1,3}$, Anna-Bella Failloux ${ }^{2} \mathbb{D}$, Francis Schaffner ${ }^{4,5}$ and \\ Jérôme Depaquit 1,3 \\ 1 Faculté de Pharmacie, Université de Reims Champagne-Ardenne, ANSES, SFR Cap Santé, EA7510 \\ ESCAPE-USC VECPAR, 51 rue Cognacq-Jay, 51096 Reims CEDEX, France; hubert.ferte@univ-reims.fr (H.F.); \\ jerome.depaquit@univ-reims.fr (J.D.) \\ 2 Arbovirus et Insectes Vecteurs, Département de Virologie, Institut Pasteur, 25-28 rue du docteur Roux, \\ 75015 Paris, France; anna-bella.failloux@pasteur.fr \\ 3 Laboratoire de Parasitologie, Hôpital Maison-Blanche, CHU de Reims, 45 rue Cognacq-Jay, \\ 51100 Reims, France \\ 4 National Centre for Vector Entomology, Institute of Parasitology, Vetsuisse Faculty, University of Zurich, \\ Rämistrasse 71, 8006 Zürich, Switzerland; fschaffner.consult@gmail.com \\ 5 Francis Schaffner Consultancy, Lörracherstrasse 50, 4125 Riehen (Basel-Land), Switzerland \\ * Correspondence: j.martinet.p@gmail.com
}

Received: 24 October 2019; Accepted: 8 November 2019; Published: 14 November 2019

check for updates

\begin{abstract}
Background: The intensification of trade and travel is linked to the growing number of imported cases of dengue, chikungunya or Zika viruses into continental Europe and to the expansion of invasive mosquito species such as Aedes albopictus and Aedes japonicus. Local outbreaks have already occurred in several European countries. Very little information exists on the vector competence of native mosquitoes for arboviruses. As such, the vectorial status of the nine mosquito species largely established in North-Western Europe (Aedes cinereus and Aedes geminus, Aedes cantans, Aedes punctor, Aedes rusticus, Anopheles claviger s.s., Anopheles plumbeus, Coquillettidia richiardii, Culex pipiens s.l., and Culiseta annulata) remains mostly unknown. Objectives: To review the vector competence of both invasive and native mosquito populations found in North-Western Europe (i.e., France, Belgium, Germany, United Kingdom, Ireland, The Netherlands, Luxembourg and Switzerland) for dengue, chikungunya, Zika, West Nile and Usutu viruses. Methods: A bibliographical search with research strings addressing mosquito vector competence for considered countries was performed. Results: Out of 6357 results, 119 references were related to the vector competence of mosquitoes in Western Europe. Eight species appear to be competent for at least one virus. Conclusions: Aedes albopictus is responsible for the current outbreaks. The spread of Aedes albopictus and Aedes japonicus increases the risk of the autochthonous transmission of these viruses. Although native species could contribute to their transmission, more studies are still needed to assess that risk.
\end{abstract}

Keywords: Aedes; Culex; Anopheles; Culiseta; transmission; West Nile; Usutu; dengue; Zika; chikungunya

\section{Introduction}

Emerging or re-emerging disease outbreaks caused by arboviruses are increasing in Europe. Usually confined to tropical or subtropical countries, their risk of occurrence in Europe (especially in the countries of Western Europe) was considered as relatively low. In a context of global change, with an increase in travel, arboviruses can more easily expand outside of their historical range. Over the last two decades, arboviruses such as dengue, Zika or chikungunya achieved incursions in European countries [1-3], causing autochthonous human infections [4-6]. Susceptible vertebrate hosts and competent vectors can interact, under appropriate environmental and climatic conditions, to cause 
outbreaks. Knowledge about the vector competence of native species and their distribution, however, remains limited. As such, overwintering thermophilic species are less likely to establish in northern European countries, as the annual isotherm becomes colder. At the present time, Aedes albopictus is considered as the vector species in autochthonous outbreaks of dengue and chikungunya in France [5]. While the vector competence of invasive species is widely studied [7-11], only a few studies are available on native species [12]. Competent native mosquitoes might have the potential to contribute to or to cause local outbreaks in addition to the risk related to invasive species [13].

In this work, we investigated the vector competence for dengue virus (DENV), Zika virus (ZIKV), chikungunya virus (CHIKV), West Nile virus (WNV) and Usutu virus (USUV) according to the geographical distribution of mosquitoes in eight Western European countries (France-Corsica excluded, Belgium, Germany, United Kingdom, Ireland, The Netherlands, Luxembourg and Switzerland).

\section{Materials and Methods}

Our area of interest is defined as the "Cfb" climate of the Köppen-Geiger climate classification [14]. Cfb defines a temperate oceanic climate (C) without a dry season (f) but with a warm summer (b) [15]. Mainland France was investigated although the south of France is characterized as a "Csa" (temperate with a dry and hot summer) or "Csb" (temperate with a dry and warm summer) category. The island of Corsica categorized as "Csb" was excluded from our analysis [15]. Mosquito inventories were then selected in our area of interest. The last European global inventory compiled by Schaffner et al. in 2001 [16] was used, completed with more recent national sources and finally compared with the last review available [17]. For invasive species, updated European Center for Disease Prevention and Control (ECDC) maps were used (https://www.ecdc.europa.eu/en/disease-vectors/surveillance-anddisease-data/mosquito-maps). The vectorial status of mosquitoes was inferred from experimental data using infections in laboratory and/or viral detections in field-collected populations.

This review follows the PRISMA Journal Publishing protocol workflow [18]; the PubMed and Web of Science databases were screened from 11 January to 15 August 2019, with keywords presented on Supplementary File 1. Full-text articles in English language containing information on mosquito vector competence were selected. Articles in other languages containing critical information were included in the data set as "identified by other sources". The PRISMA flow chart is described in Figure 1.

Records identified through database $(n=6,297)$
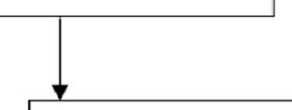

Records after duplicates removed ( $n=5,067$ )

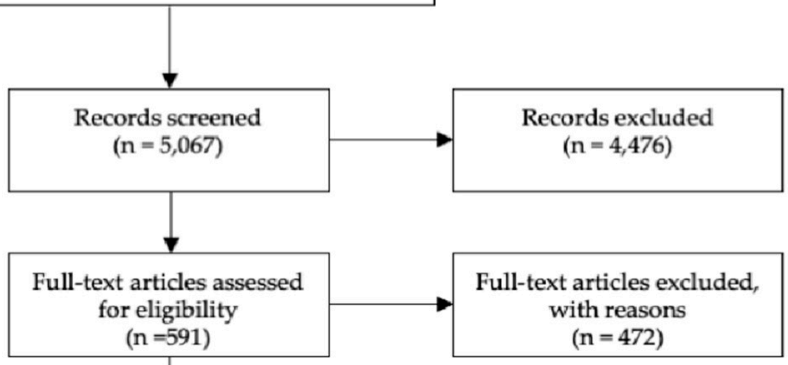

Studies included in qualitative synthesis $(\mathrm{n}=119)$

Figure 1. PRISMA flow chart. 


\section{Results}

The compilation of mosquito inventories is summarized in Table 1. A detailed checklist is shown in Table 2, with the nine ubiquitous species highlighted in grey. Some species complexes (i.e., Aedes cinereus/geminus, Anopheles maculipennis complex, and Culex pipiens complex) were not identified at the species and/or biotype level. In these cases, the species denomination was annotated with an asterisk.

Detailed vector competence studies by species are presented in Table 3. Positive and negative results reported here are related to our area of study. Vector competence is defined as the ability of a mosquito to ingest, replicate and transmit a virus by biting. Firstly, species are considered to be competent if viral replication and detection of viral particles in saliva have been demonstrated. On the other hand, we do not consider the detection of viral RNA in mosquito pools as a relevant indication of vector competence. This information, however, may suggest an active virus circulation which could warrant further vector competence studies to identify potential vectors.

Results from experimental infections of European mosquito populations are listed in Table 4.

Table 1. Number of mosquito species recorded per country [16,19-25].

\begin{tabular}{ccccccccc}
\hline & Belgium & France & Germany & Ireland & Luxembourg & Switzerland & $\begin{array}{c}\text { The } \\
\text { Netherlands }\end{array}$ & UK \\
\hline No. of species & 33 & 57 & 49 & 20 & 15 & 35 & 38 & 34 \\
\hline
\end{tabular}


Table 2. Checklist of mosquitoes recorded per country. Species in grey rows were recorded in all the countries investigated in the study. X: species recorded; -: species not recorded; i: introduced species; species complexes for which final identification could not be achieved are labelled with an asterisk.

\begin{tabular}{|c|c|c|c|c|c|c|c|c|}
\hline & Belgium & France & Germany & Ireland & Luxembourg & Netherlands & Switzerland & $\begin{array}{c}\text { United } \\
\text { Kingdom }\end{array}$ \\
\hline Aedes (Acartomyia) mariae (Sergent and Sergent, 1903) & - & $\mathrm{x}$ & - & - & - & - & - & - \\
\hline $\begin{array}{c}\text { Aedes (Aedes) cinereus Meigen, } 1818^{*} \text { and Aedes (Aedes) } \\
\text { geminus Peus, } 1970 \text { * }\end{array}$ & $x$ & $x$ & $\mathrm{x}$ & $x$ & $x$ & $\mathrm{X}$ & $x$ & $x$ \\
\hline $\begin{array}{c}\text { Aedes (Aedes) rossicus Dolbeskin, Gorickaja and } \\
\text { Mitrofanova, } 1930\end{array}$ & - & $\mathrm{x}$ & $\mathrm{x}$ & - & - & - & - & - \\
\hline Aedes (Aedimorphus) vexans (Meigen, 1830) & $x$ & $x$ & $x$ & - & - & $x$ & $x$ & $x$ \\
\hline Aedes (Dahliana) geniculatus (Olivier, 1791) & $\mathrm{x}$ & $\mathrm{x}$ & $\mathrm{x}$ & - & $\mathrm{x}$ & $\mathrm{x}$ & $\mathrm{x}$ & $\mathrm{x}$ \\
\hline Aedes (Fredwarsius) vittatus (Bigot, 1861) & - & $x$ & - & - & - & - & - & - \\
\hline Aedes (Hulecoeteomyia) japonicus (Theobald 1901) & $x$ & $x$ & $X$ & - & - & $x$ & $x$ & - \\
\hline Aedes (Hulecoeteomyia) koreicus (Edwards 1917) & $x$ & - & $\mathrm{i}$ & - & - & - & $x$ & - \\
\hline Aedes (Ochlerotatus) annulipes (Meigen, 1830) & $\mathrm{x}$ & $\mathrm{x}$ & $\mathrm{X}$ & - & $\mathrm{x}$ & $\mathrm{x}$ & $\mathrm{X}$ & $x$ \\
\hline Aedes (Ochlerotatus) berlandi Séguy, 1921 & - & $x$ & - & - & - & - & - & - \\
\hline Aedes (Ochlerotatus) cantans (Meigen, 1818) & $\mathrm{x}$ & $\mathrm{x}$ & $\mathrm{X}$ & $\mathrm{X}$ & $\mathrm{X}$ & $\mathrm{X}$ & $x$ & $\mathrm{X}$ \\
\hline Aedes (Ochlerotatus) caspius (Pallas, 1771) & $\mathrm{X}$ & $\mathrm{X}$ & $x$ & $X$ & - & $X$ & $x$ & $x$ \\
\hline Aedes (Ochlerotatus) cataphylla Dyar, 1916 & - & $x$ & $x$ & - & - & - & $x$ & - \\
\hline Aedes (Ochlerotatus) coluzzi Rioux, Guilvard and Pasteur, 1998 & - & $x$ & - & - & - & - & - & - \\
\hline Aedes (Ochlerotatus) communis (DeGeer, 1776) & $x$ & $\mathrm{x}$ & $X$ & - & - & $x$ & $x$ & $x$ \\
\hline Aedes (Ochlerotatus) detritus Haliday, 1833 & $\mathrm{x}$ & $\mathrm{x}$ & $\mathrm{x}$ & $\mathrm{x}$ & - & $\mathrm{x}$ & - & $\mathrm{x}$ \\
\hline Aedes (Ochlerotatus) diantaeus Howard, Dyar and Knab, 1912 & - & $\mathrm{x}$ & $x$ & - & - & - & - & - \\
\hline Aedes (Ochlerotatus) dorsalis (Meigen, 1830) & $x$ & $\mathrm{x}$ & $x$ & $x$ & - & $x$ & $x$ & $x$ \\
\hline Aedes (Ochlerotatus) excrucians (Walker, 1856) & - & - & $\mathrm{X}$ & - & - & $\mathrm{x}$ & $x$ & - \\
\hline Aedes (Ochlerotatus) flavescens (Müller, 1764) & $x$ & $x$ & $x$ & - & - & $x$ & $x$ & $x$ \\
\hline Aedes (Ochlerotatus) leucomelas (Meigen, 1804) & - & - & $x$ & - & - & $x$ & - & $x$ \\
\hline Aedes (Ochlerotatus) nigrinus (Eckstein, 1918) & - & $x$ & $x$ & - & - & $x$ & - & - \\
\hline Aedes (Ochlerotatus) pulcritarsis (Rondani, 1872) & - & $x$ & - & - & - & - & - & - \\
\hline Aedes (Ochlerotatus) pullatus (Coquillett, 1904) & - & $x$ & $x$ & - & - & - & $x$ & - \\
\hline Aedes (Ochlerotatus) punctor (Kirby, 1837) & $\mathrm{X}$ & $x$ & $X$ & $X$ & $X$ & $X$ & $X$ & $X$ \\
\hline Aedes (Ochlerotatus) riparius Dyar and Knab, 1907 & - & - & $X$ & - & - & $X$ & - & - \\
\hline Aedes (Ochlerotatus) sticticus (Meigen, 1838) & $x$ & $x$ & $\mathrm{x}$ & - & $x$ & $\mathrm{x}$ & $x$ & $\mathrm{x}$ \\
\hline Aedes (Ochlerotatus) surcoufi (Theobald, 1912) & - & $x$ & - & - & - & - & - & - \\
\hline Aedes (Rusticoidus) refiki Medschid, 1928 & - & $x$ & $X$ & - & - & - & $X$ & - \\
\hline Aedes (Rusticoidus) rusticus (Rossi, 1790) & $x$ & $x$ & $\mathrm{X}$ & $x$ & $\mathrm{x}$ & $\mathrm{x}$ & $\mathrm{X}$ & $\mathrm{X}$ \\
\hline Aedes (Stegomyia) aegypti (Linnaeus,1762) & - & - & - & - & - & $\mathrm{i}$ & - & - \\
\hline Aedes (Stegomyia) albopictus (Skuse, 1894) & $x$ & $\mathrm{x}$ & $\mathrm{x}$ & - & - & $x$ & $\mathrm{x}$ & - \\
\hline Anopheles (Anopheles) algeriensis (heobald, 1903 & - & $\mathrm{x}$ & $\mathrm{x}$ & $x$ & - & $\mathrm{X}$ & - & $\mathrm{X}$ \\
\hline Anopheles (Anopheles) atroparvus Van Thiel, 1927 & $\mathrm{x}$ & $\mathrm{x}$ & $x$ & $x$ & - & $\mathrm{x}$ & - & $x$ \\
\hline
\end{tabular}


Table 2. Cont

\begin{tabular}{|c|c|c|c|c|c|c|c|c|}
\hline & Belgium & France & Germany & Ireland & Luxembourg & Netherlands & Switzerland & $\begin{array}{c}\text { United } \\
\text { Kingdom }\end{array}$ \\
\hline Anopheles (Anopheles) claviger (Meigen, 1804) sensu stricto & $\mathrm{x}$ & $\mathrm{x}$ & $\mathrm{x}$ & $\mathrm{X}$ & $\mathrm{X}$ & $\mathrm{x}$ & $\mathrm{x}$ & $\mathrm{x}$ \\
\hline Anopheles (Anopheles) hyrcanus (Pallas, 1771) & - & $\mathrm{X}$ & - & - & - & - & - & - \\
\hline Anopheles (Anopheles) maculipennis Meigen, 1818 sensu lato* & $\mathrm{x}$ & $x$ & $X$ & - & - & $X$ & $X$ & - \\
\hline Anopheles (Anopheles) melanoon Hackett, 1934 & - & $\mathrm{x}$ & - & - & - & $X$ & - & - \\
\hline Anopheles (Anopheles) messeae Falleroni, 1926 & $x$ & $x$ & $x$ & $x$ & - & $x$ & - & $x$ \\
\hline Anopheles (Anopheles) petragnani Del Vecchio, 1939 & - & $\mathrm{x}$ & $x$ & - & - & - & - & - \\
\hline Anopheles (Anopheles) plumbeus Stephens, 1828 & $\mathrm{X}$ & $\mathrm{X}$ & $\mathrm{X}$ & $\mathrm{X}$ & $\mathrm{X}$ & $\mathrm{X}$ & $\mathrm{x}$ & $\mathrm{X}$ \\
\hline Coquillettidia (Coquillettidia) buxtoni (Edwards, 1923) & - & $\mathrm{X}$ & - & - & - & - & $X$ & - \\
\hline Coquillettidia (Coquillettidia) richiardii (Ficalbi, 1889) & $\mathrm{x}$ & $\mathrm{x}$ & $\mathrm{x}$ & $\mathrm{X}$ & $\mathrm{X}$ & $\mathrm{X}$ & $\mathrm{X}$ & $\mathrm{X}$ \\
\hline Culex (Barraudius) modestus Ficalbi, 1889 & - & $\mathrm{X}$ & $\mathrm{X}$ & - & - & $\mathrm{X}$ & $\mathrm{X}$ & $\mathrm{X}$ \\
\hline Culex (Culex) mimeticus Noé, 1899 & - & $x$ & - & - & - & - & - & - \\
\hline Culex (Culex) pipiens Linnaeus, 1758 sensu lato* & $\mathrm{x}$ & $\mathrm{x}$ & $\mathrm{X}$ & $\mathrm{X}$ & $\mathrm{X}$ & $\mathrm{x}$ & $\mathrm{x}$ & $\mathrm{X}$ \\
\hline Culex (Culex) pipiens biotype pipiens Linnaeus, 1758 & $\mathrm{x}$ & - & $X$ & $\mathrm{X}$ & - & - & - & $X$ \\
\hline Culex (Culex) pipiens biotype molestus Forskål, 1775 & $x$ & - & $\mathrm{x}$ & - & - & - & - & $\mathrm{x}$ \\
\hline Culex (Culex) theileri Theobald, 1903 & - & $x$ & - & - & - & - & - & - \\
\hline Culex (Culex) torrentium Martini, 1925 & $x$ & $x$ & $x$ & - & $x$ & $X$ & $X$ & $X$ \\
\hline Culex (Maillotia) hortensis Ficalbi, 1889 & $\mathrm{x}$ & $\mathrm{x}$ & $\mathrm{x}$ & - & - & - & $x$ & - \\
\hline $\begin{array}{c}\text { Culex (Neoculex) europaeus Ramos et al., } 2003 \text { (syn. Culex } \\
\text { territans Walker, 1856) }\end{array}$ & $x$ & $\mathrm{x}$ & $x$ & - & $x$ & $x$ & $x$ & $x$ \\
\hline Culex (Neoculex) impudicus Ficalbi, 1890 & - & $x$ & - & - & - & - & - & - \\
\hline Culex (Neoculex) martinii Medschid, 1930 & - & $x$ & $x$ & - & - & - & $X$ & - \\
\hline Culiseta (Allotheobaldia) longiareolata (Macquart, 1838) & - & $\mathrm{x}$ & $\mathrm{x}$ & - & - & - & $\mathrm{x}$ & $\mathrm{X}$ \\
\hline Culiseta (Culicella) fumipennis (Stephens, 1825) & $x$ & $x$ & - & - & - & $x$ & $x$ & $x$ \\
\hline Culiseta (Culicella) litorea (Shute, 1928) & - & $\mathrm{x}$ & - & $x$ & - & - & - & $x$ \\
\hline Culiseta (Culicella) morsitans (Theobald, 1901) & $x$ & $x$ & $x$ & $x$ & - & $x$ & $x$ & $x$ \\
\hline Culiseta (Culicella) ochroptera (Peus, 1935) & - & - & $x$ & - & - & $x$ & - & - \\
\hline Culiseta (Culiseta) alaskaensis (Ludlow, 1906) & - & $\mathrm{x}$ & $x$ & $\mathrm{x}$ & - & $\mathrm{x}$ & $\mathrm{x}$ & $x$ \\
\hline Culiseta (Culiseta) annulata (Schrank, 1776) & $x$ & $x$ & $x$ & $x$ & $x$ & $x$ & $x$ & $x$ \\
\hline Culiseta (Culiseta) glaphyroptera (Schiner, 1864) & - & $\mathrm{x}$ & $X$ & - & - & - & - & - \\
\hline Culiseta (Culiseta) subochrea (Edwards, 1921) & $\mathrm{X}$ & $\mathrm{X}$ & $\mathrm{x}$ & $\mathrm{X}$ & - & $\mathrm{X}$ & - & $\mathrm{X}$ \\
\hline Orthopodomyia pulcripalpis (Rondani, 1872) & $x$ & $x$ & - & - & - & - & - & $x$ \\
\hline Uranotaenia (Pseudoficalbia) unguiculata Edwards, 1913 & - & $x$ & $x$ & - & - & - & - & - \\
\hline
\end{tabular}


Table 3. Vector competence studies on European mosquito populations. Negative and positive experiments are written in normal and bold typeface, respectively. Studies related to our area of concern are indicated by a reference number. Studies related to experiments carried out outside of our area of concern are indicated with a reference number and an additional letter: E: Europe; W: elsewhere in the world. Since no capture of chikungunya virus (CHIKV), dengue virus (DENV) and Zika virus (ZIKV) has been reported in our area of concern, these viruses are not mentioned in the field data part of the table.

\begin{tabular}{|c|c|c|c|c|c|c|c|}
\hline & \multicolumn{5}{|c|}{ Laboratory Experiment } & \multicolumn{2}{|c|}{ Field Data } \\
\hline & Dengue & Chikungunya & Zika & Usutu & West Nile & Usutu & West Nile \\
\hline Aedes cinereus ${ }^{*}$, Aedes geminus * & - & - & - & - & - & - & [26], W [27] \\
\hline Aedes rossicus & - & - & - & - & - & - & {$[26], \mathrm{E}[28]$} \\
\hline Aedes vexans & - & E [13] & $\mathbf{W}[29,30]$ & - & $\mathbf{W}[31]$ & $\mathrm{E}[32]$ & {$[26], \mathrm{E}[32], \mathrm{W}[27,33,34]$} \\
\hline Aedes geniculatus & - & E [35] & - & - & [36] & - & [26] \\
\hline Aedes japonicus & [11] & [11] & [37] & - & {$[10,38]$} & - & $\mathbf{W}$ [39] \\
\hline Aedes koreicus & - & $\mathrm{E}$ [9] & - & - & & - & - \\
\hline Aedes annulipes & - & - & - & - & - & - & [26] \\
\hline Aedes cantans & - & - & - & - & - & - & E [40] \\
\hline Aedes caspius & - & - & - & - & {$[41]$} & - & $\mathrm{E}$ [42] \\
\hline Aedes detritus & [12] & [12] & - & - & [12] & $\mathrm{E}[42]$ & - \\
\hline Aedes dorsalis & - & - & - & - & W [43] & - & W [34] \\
\hline Aedes sticticus & - & - & $\mathrm{W}[30]$ & - & - & - & {$[26], \mathbf{W}[34]$} \\
\hline Aedes albopictus & W [44] & [45] & {$[8,46]$} & E [47] & W [48] & $\mathrm{E}[42]$ & W [49] \\
\hline Anopheles claviger sensu lato & - & - & - & - & - & - & [26] \\
\hline Anopheles maculipennis sensu lato * & - & $\mathrm{E}[13]$ & - & - & - & $\mathrm{E}[42]$ & {$[26]$} \\
\hline Anopheles plumbeus & - & - & - & - & [36] & - & [26] \\
\hline Coquillettidia richiardii & - & - & - & - & - & - & [26], E [40] \\
\hline Culex modestus & - & - & - & - & {$[41,50]$} & - & [26], E [42] \\
\hline Culex pipiens sensu lato* & - & - & {$[8]$} & {$[51,52]$} & {$[41,51,53-56]$} & {$[6,57-60], \mathrm{E}[42]$} & {$[26,61], \mathrm{E}[42]$} \\
\hline Culex torrentium & - & - & {$[8], \mathrm{E}[8,62]$} & - & [56] & [59] & - \\
\hline Culex europaeus & - & - & - & - & - & $\mathrm{E}[32]$ & W [34] \\
\hline Culiseta annulata & - & - & - & - & - & $\mathrm{E}[32,42]$ & [26] \\
\hline Culiseta morsitans & - & - & - & - & - & - & $\mathbf{W}[40]$ \\
\hline Uranotaenia unguiculata & - & - & - & - & - & - & E [63-65] \\
\hline
\end{tabular}

*: species complexes for which final identification could not be achieved. 
Table 4. Experimental infections performed with North-Western European mosquito populations.

\begin{tabular}{|c|c|c|c|c|c|c|c|c|}
\hline Species & Country & Locality & Titer of Blood Meal & Virus Strain & Infection & Transmission & $\begin{array}{l}\text { Days Post } \\
\text { Infection }\end{array}$ & Reference \\
\hline Aedes vexans & France & Côte d'Azur & $10^{7} \mathrm{PFU} / \mathrm{mL}$ & CHIKV 06.21 La Réunion 2005 & NA & - & $12-14$ & [7] \\
\hline Aedes japonicus japonicus & Switzerland & Zürich & $10^{7} \mathrm{ffu} / \mathrm{mL}$ & CHIKV 06.21 La Réunion 2005 & + & + & 14 & [11] \\
\hline Aedes japonicus japonicus & Switzerland & Zürich & $10^{7} \mathrm{ffu} / \mathrm{mL}$ & $\begin{array}{l}\text { DENV Serotype 2, Bangkok } \\
\text { Thailand }\end{array}$ & + & + & 14 & [11] \\
\hline Aedes japonicus japonicus & Switzerland & Zürich & $10^{6} \mathrm{TCID} 50 / \mathrm{mL}$ & $\begin{array}{l}\text { West Nile virus (WNV) lineage } 1 \\
\text { FIN Italy }\end{array}$ & + & + & 14 & [10] \\
\hline Aedes japonicus japonicus & Germany & Stuttgart & $2 \times 10^{7} \mathrm{PFU} / \mathrm{mL}$ & WNV lineage 1 strain NY99 & - & - & 14 & [38] \\
\hline Aedes japonicus japonicus & Switzerland & Zürich & $10^{6} \mathrm{TCID} 50 / \mathrm{mL}$ & WNV lineage 1 strain NY99 & + & + & 14 & [10] \\
\hline Aedes japonicus japonicus & Germany & - & $10^{7} \mathrm{PFU} / \mathrm{mL}$ & ZIKV_FB-GWUH-2016 & + & + & 14 & [37] \\
\hline Aedes caspius & France & Camargue & $10^{10,3} \mathrm{PFU} / \mathrm{mL}$ & WNV PaAn001 AY268135 & + & - & 14 & [41] \\
\hline Aedes detritus & France & Côte d'Azur & $10^{7} \mathrm{PFU} / \mathrm{mL}$ & CHIKV 06.21 La Réunion 2005 & NA & + & $12-14$ & [7] \\
\hline Aedes detritus & United Kingdom & Little Neston & $10^{7} \mathrm{PFU} / \mathrm{mL}$ & CHIKV NC/ 2011-568 & - & - & 17 & [12] \\
\hline Aedes detritus & United Kingdom & Little Neston & $10^{7} \mathrm{PFU} / \mathrm{mL}$ & $\begin{array}{c}\text { DENV Serotype 2, Bangkok } \\
\text { Thailand }\end{array}$ & - & - & 17 & [12] \\
\hline Aedes detritus & United Kingdom & Little Neston & $2 \times 10^{6} \mathrm{PFU} / \mathrm{mL}$ & $\begin{array}{c}\text { 1hailand } \\
\text { WNV NY-99 }\end{array}$ & + & + & 17 & [12] \\
\hline Aedes albopictus & France & Bar-sur-Loup & $10^{6,5} \mathrm{PFU} / \mathrm{mL}$ & CHIKV 06.21 La Réunion 2005 & + & + & $3,5,7$ & [45] \\
\hline Aedes albopictus & France & Côte d'Azur & $10^{7} \mathrm{PFU} / \mathrm{mL}$ & CHIKV 06.21 La Réunion 2005 & NA & + & $12-14$ & [7] \\
\hline Aedes albopictus & France & Bar-sur-Loup & $10^{6,5} \mathrm{PFU} / \mathrm{mL}$ & CHIKV 202352013 & + & + & $3,5,7$ & [45] \\
\hline Aedes albopictus & France & Nice & $10^{7} \mathrm{TCID} 50 / \mathrm{mL}$ & ZIKV strain (NC-2014-5132) & + & + & 14 & {$[46]$} \\
\hline Culex modestus & France & Camargue & $10^{10,3} \mathrm{PFU} / \mathrm{mL}$ & WNV PaAn001 AY268132 & + & + & 14 & [50] \\
\hline Culex modestus & France & Camargue & $10^{10,3} \mathrm{PFU} / \mathrm{mL}$ & WNV PaAn001 AY268134 & + & + & 14 & [41] \\
\hline Culex pipiens hybrid form & United Kingdom & - & $10^{6} \mathrm{PFU} / \mathrm{mL}$ & $\begin{array}{c}\text { Usutu virus (USUV) African strain } \\
\text { SAAR-1776 }\end{array}$ & - & - & 14 & [52] \\
\hline Culex pipiens hybrid form & Netherlands & - & $5.2 \times 10^{7} \mathrm{TCID} 50 / \mathrm{mL}$ & WNV lineage 2 strain Greece 2010 & + & + & 14 & [54] \\
\hline Culex pipiens molestus & Germany & $\begin{array}{l}\text { Heidelberg, } \\
\text { Wendland, and } \\
\text { Langenhelsten }\end{array}$ & $1-1.6 \times 10^{7} \mathrm{PFU} / \mathrm{mL}$ & WNV lineage 1 strain NY99 & + & + & 14 & [56] \\
\hline Culex pipiens molestus & Netherlands & Amsterdam & $5.2 \times 10^{7} \mathrm{TCID} 50 / \mathrm{mL}$ & WNV lineage 2 strain Greece 2010 & + & + & 14 & [54] \\
\hline Culex pipiens molestus & Germany & Langenhelsten & $10^{7} \mathrm{PFU} / \mathrm{mL}$ & ZIKV_FB-GWUH-2016 & + & - & - & [8] \\
\hline
\end{tabular}


Table 4. Cont.

\begin{tabular}{|c|c|c|c|c|c|c|c|c|}
\hline Species & Country & Locality & Titer of Blood Meal & Virus Strain & Infection & Transmission & $\begin{array}{l}\text { Days Post } \\
\text { Infection }\end{array}$ & Reference \\
\hline Culex pipiens pipiens & United Kingdom & - & $10^{6} \mathrm{PFU} / \mathrm{mL}$ & USUV African strain SAAR-1776 & + & + & 14 & [52] \\
\hline Culex pipiens pipiens & Germany & Hamburg & $1-1.6 \times 10^{7} \mathrm{PFU} / \mathrm{mL}$ & WNV lineage 1 strain NY99 & + & + & 14 & [56] \\
\hline Culex pipiens pipiens & Netherlands & Best & $5.2 \times 10^{7} \mathrm{TCID} 50 / \mathrm{mL}$ & WNV lineage 2 strain Greece 2010 & + & + & 14 & [54] \\
\hline Culex pipiens pipiens & Germany & - & $10^{7} \mathrm{PFU} / \mathrm{mL}$ & ZIKV_FB-GWUH-2016 & + & - & - & [8] \\
\hline Culex pipiens s.l. & France & Côte d'Azur & $10^{7} \mathrm{PFU} / \mathrm{mL}$ & CHIKV 06.21 La Réunion 2005 & NA & - & $12-14$ & [7] \\
\hline Culex pipiens s.l. & Netherlands & Brummen & $4 \times 10^{7} \mathrm{TCID} 50 / \mathrm{mL}$ & USUV Bologna 2009 & + & + & 14 & [51] \\
\hline Culex pipiens s.l. & Switzerland & Zürich & $10^{2.6}$ to $10^{4.2} \mathrm{PFU} / \mathrm{mL}$ & WNV lineage 1 FIN Italy & + & - & 14 & [55] \\
\hline Culex pipiens s.l. & Switzerland & Zürich & $10^{2.6}$ to $10^{4.2} \mathrm{PFU} / \mathrm{mL}$ & WNV lineage 1 strain NY99 & + & + & 14 & [55] \\
\hline Culex pipiens s.l. & Netherlands & Brummen & $1.4 \times 10^{8} \mathrm{TCID} 50 / \mathrm{ml}$ & WNV lineage 2 strain Greece 2010 & + & + & 14 & [53] \\
\hline Culex pipiens s.l. & France & Camargue & $10^{10,3} \mathrm{PFU} / \mathrm{mL}$ & WNV PaAn001 AY268133 & + & + & 14 & [41] \\
\hline Culex torrentium & Germany & Hamburg & $1-1,6 \times 10^{7} \mathrm{PFU} / \mathrm{mL}$ & WNV lineage 1 strain NY99 & + & + & 14 & [56] \\
\hline Culex torrentium & Germany & - & $10^{7} \mathrm{PFU} / \mathrm{mL}$ & ZIKV_FB-GWUH-2016 & + & - & 14,21 & [8] \\
\hline
\end{tabular}


A Brief Summary of the Reviewed Arboviruses Is Presented Below

\subsection{Chikungunya Virus}

Chikungunya virus (genus Alphavirus, family Togaviridae) was reported for the first time in 1952-1953 in Tanzania [66]. The original anthroponotic cycle allows the virus to circulate from Aedes mosquitoes to non-human primates. Outbreaks occur when an anthropophilic or opportunistic mosquito (e.g., Aedes aegypti, Ae. albopictus) completes the bridge between zoonotic and anthroponotic cycles. The girst reported outbreaks occurred in the southern hemisphere during the 1960s [67]. Since then, three lineages have been identified: West-African, East-Central-South-African, and Asian lineages. During the 2000s, a new variant harboring a point mutation at the E1 glycoprotein gene (E1-A226V) was isolated during the outbreak in the islands of the Indian Ocean, making Ae. albopictus more efficient for the transmission of CHIKV [68]. In Europe, the autochthonous transmission of CHIKV was first reported in Italy in 2007 [69]. In our area of interest, the first autochthonous cases of CHIKV occurred in 2010 in Southern France [70]. According to the ECDC, the six countries in this study reported 214 imported cases (Switzerland excluded) in 2012-2016 [71]. An autochthonous circulation of CHIKV was observed in France 2014 and 2017 [4,70,72]. An autochthonous outbreak of CHIKV also occurred in Italy in 2017 [73].

French Ae. albopictus and German Ae. japonicus are competent for CHIKV [11,45]. Aedes detritus from the UK was found inefficient to transmit CHIKV [12]. Aedes vexans from Northern Italy showed a low disseminated infection rate and its role in CHIKV transmission should not be neglected [13]. In Europe, the declaration of imported cases of CHIKV shows three temporal peaks, namely February, April, and August to November (Figure 2) [71]—-periods at which travelers return from endemic areas. While mosquitoes are absent in February, they become active in April; the dynamics of Ae. japonicus, Ae. koreicus and Ae. albopictus coincide with the peaks of imported cases promoting autochthonous transmission.

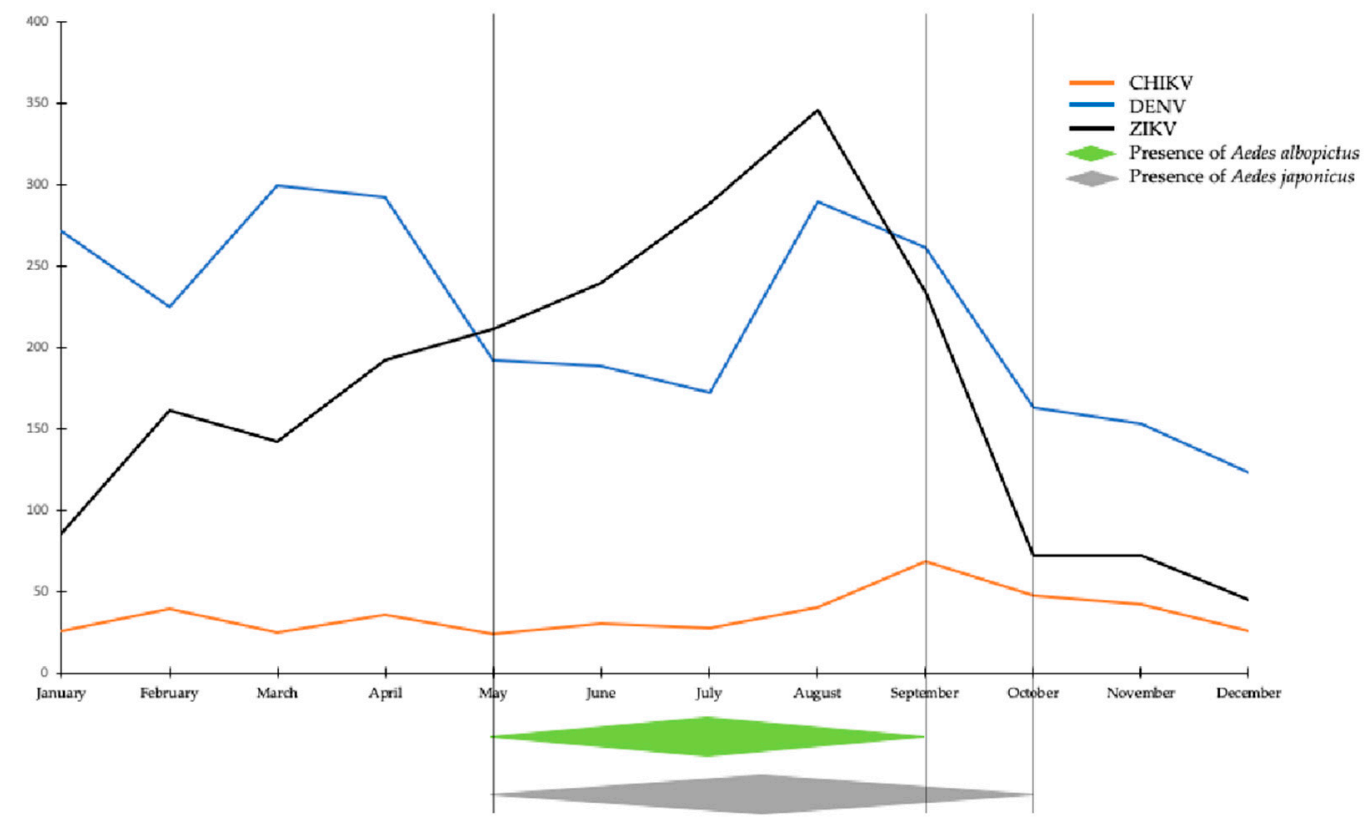

Figure 2. Number of imported cases of chikungunya, dengue and Zika viruses in Europe in 2016 (adapted from $[71,74,75])$.

\subsection{Dengue Virus}

Dengue virus (genus Flavivirus, family Flaviviridae) includes four serotypes (DENV-1 to DENV-4). It is the most widespread arbovirus in the world and is reported in over 100 countries [76]. Aedes aegypti and Ae. albopictus are the main vectors of DENV acting in urban cycles. According to the latest ECDC 
annual epidemiological report, covering the 2012-2016 period, 1562 cases (Switzerland excluded) were reported in our study area [74]. The first autochthonous cases of dengue fever were reported in our area of interest (France) in 2010 [77]. Other outbreaks in 2013 and 2015 also occurred in Southern France [5,78], where Ae. albopictus is well established and found in abundance [7].

Field-collected Ae. japonicus (Germany) and Ae. detritus (United Kingdom) were tested for their competence toward a DENV Serotype 2 isolated in Bangkok (Thailand); only Ae. japonicus was competent [12,55].

According to the ECDC [74], the frequency of imported cases shows three peaks: January, from March to April, and from August to September (Figure 2). Mosquitoes are only active during the second and third peaks.

\subsection{Zika Virus}

Zika virus (genus Flavivirus, family Flaviviridae), was first isolated in the Zika forest of Uganda in 1947 [79]. Since the Yap island epidemic in 2007, ZIKV has circulated on all continents except Europe [80]. There are three main lineages: two from Africa and one from Asia [81]. It is transmitted to humans (urban cycle) and primates (sylvatic cycle) by mosquitoes of the Aedes genus. In North-Western Europe, Ae. albopictus (France, Germany) and Ae. japonicus (Germany) are competent mosquitoes [8,37,46]. Conversely, Culex pipiens s.l. and Cx. pipiens molestus are not competent for ZIKV [8].

According to the ECDC 2016 annual epidemiological report [75], ZIKV case reports are steadily increasing from January to reach a peak in August then decrease rapidly to end in October (Figure 2). European Ae. albopictus is competent to transmit ZIKV [8] and Ae. japonicus is poorly competent [37].

\subsection{Usutu Virus}

Usutu virus (genus Flavivirus, family Flaviviridae) was initially isolated in South Africa in 1959 [82]. USUV was considered as exclusively transmitted in Africa until the first European outbreak occurred in Italy in 1996 [83]. Since then, USUV emerged in five countries studied in this paper (Belgium, France, Germany, Switzerland, and The Netherlands) [84]. USUV antibodies have been detected in resident and migratory birds in each country of our area of concern [85-90], except Ireland and Luxembourg. There are eight lineages of USUV. Five are European (European lineage 1-5) and three are African (African lineage 1-3) [84]. The first human cases were reported in Africa in 1981 [91], and the first human neuroinvasive cases were reported in Italy in 2009 [92]. USUV is transmitted in Europe by $C x$. pipiens mosquitoes [51]. The reservoir hosts of USUV are migratory and resident birds. USUV or antibodies have been detected in 58 bird species belonging to 26 families and 13 orders [93]. Blackbirds (Turdus merula) seem to have the highest mortality rate among bird species affected by USUV [94]. An exhaustive review about WNV and USUV has been published [93]. Cx. pipiens s.l. from The Netherlands and the UK have been tested as competent for USUV strains, Bologna 2009 and SAAR-1776 [51,52].

While $C x$. pipiens s.l. is considered the principal vector in temperate regions, Italian Ae. albopictus has been experimentally tested for USUV, with no clear-cut results [47]. Ae. japonicus from Austria has been found positive to virus dissemination [95]. To our knowledge, no other mosquito species of NW Europe has been demonstrated to be competent for USUV.

\subsection{West Nile Virus}

West Nile virus (genus Flavivirus, family Flaviviridae) was first recorded in the West Nile district of Uganda in 1937 [96]. In natural conditions, it circulates between birds and bird-feeding mosquitoes. Mammals (mainly horses and humans) are considered dead-end hosts [97]. In Europe, WNV is mainly transmitted by Culex mosquitoes. The first documented introduction of WNV in metropolitan France dates from 1962, in Camargue [98]. The vector incriminated in 1964 was Culex modestus [99]. During the following 40 years, WNV did not cause any human cases in France, and a low prevalence of antibodies was observed in human and equine populations during the 1970s [98]. The resurgence of WNV in 
France occurred in 2000 with 76 laboratory confirmed equine cases. Sporadic detections of positive serology in humans and birds occurred during the following 15 years [88,100], until a new epidemic outbreak occurred in 2015 in southern France [101]. Three years later, an outbreak occurred for the first time in Germany [102]. The number of cases reported to the ECDC for 2018 was exceptionally high [103].

European mosquitoes display a variable susceptibility to WNV infection and transmission. Culex spp. from France, The Netherlands, Switzerland and Germany are competent for WNV lineages 1 and 2. Culex pipiens biotype pipiens, Culex pipiens biotype molestus and Culex torrentium from the studied area (France, The Netherlands, Switzerland and Germany) are competent for WNV lineage 1 and $2[41,51,53,55,56,104]$. Culex pipiens s.l. from Switzerland is susceptible to WNV infection but is not competent for WNV lineage 1 FIN Italy [55]. The competence of Ae. detritus (United Kingdom) was demonstrated for WNV lineage 1 strain NY99 [12].

The vector competence of other field-collected species has not been successfully demonstrated for WNV: Ae. caspius (France) is susceptible to infection but not able to transmit [41]. Ae. japonicus (Germany) could not be infected nor transmit WNV lineage 1 strain NY99 [38].

\section{Discussion}

North-Western Europe is at risk for emerging or re-emerging arboviruses. The epidemiology of arboviruses such as DENV, ZIKV or CHIKV is very different in Europe as compared to tropical or sub-tropical countries. In the latter countries, the existence of sylvatic cycles involving wild animals as reservoir hosts and arboreal canopy dwelling mosquitoes as vectors sustain a viral circulation of viruses all year long [105]. Epidemics only occur when anthropo-zoophilic mosquitoes act as bridge vector for the transmission of the virus from animals to humans. In Europe, in the absence of any sylvatic cycle, autochthonous transmission is only caused when a competent vector becomes infectious after feeding on an imported human case.

The number of imported human cases of CHIKV, DENV and ZIKV peaks in January, March-April, and September-October [71,74,75], corresponding to vacations in Europe. The last two peaks may allow the launch of local transmissions. Regarding the January peak, there is no mosquito activity at that time in the considered area. Consequently, this peak will probably have no consequences regarding a local transmission. During the March-April peak, DENV and CHIKV can be transmitted by Ae. japonicus [23], and ZIKV by Ae. vexans if European mosquitoes appear to be competent (such as Canadian ones do) [30]. The summer peak is highly correlated with the activity of Ae. albopictus. The competence of native populations has been characterized for CHIKV and ZIKV $[8,45,46]$. Outbreaks have already occurred in southern European countries such as the occurrence of chikungunya in Italy [73] and dengue in France [5]. Established vectors Ae. albopictus are also competent for transmitting ZIKV in Italy and Spain $[106,107]$.

To date, Ae. albopictus and Ae. japonicus are the main species that could represent a risk of the transmission of the considered arboviruses in our area of interest. Indeed, native Ae. albopictus and Ae. japonicus can transmit CHIKV, DENV, ZIKV [11,37,45,46].

This work highlights that invasive species represent the most probable candidates for the circulation of CHIKV, DENV, and ZIKV in our area of interest. To date, three species are established in our area of interest: Ae. albopictus, Ae. koreicus and Ae. japonicus. Ae. albopictus was first introduced in France in 1999 and has been established since 2004 [49]. It is now widespread and abundant in the southern part of the country. It is also reported as established in the north-eastern part of France, in Germany, in Switzerland, in The Netherlands, and occasionally found in Belgium and the UK [108]. Similarly, Ae. japonicus is well established in Belgium, France, Luxembourg, Germany, The Netherlands, and Switzerland [109,110]. Ae. koreicus is implanted in Germany, Switzerland, and Belgium [111]. While invasive species benefit from globalization (increased transportation of goods and people) to expand, native species are also experiencing ecological upheavals and contribute to increase the risk of 
arboviral emergences. Recently, An. plumbeus has switched from natural breeding sites to man-made sites [112] leading to consider its potential role as a vector for WNV [36].

While the vector competence of Ae. albopictus for the five viruses considered in this study has been largely examined, European native mosquitoes (Anopheles, Culiseta, Coquillettidia, Uranotaenia) were poorly investigated. The role of ornithophilic species, such as Cs. morsitans, and opportunistic species (mosquitoes that feed on mammalians as well as on birds or amphibians) like An. plumbeus or Ae. geniculatus, is still unknown, especially in the transmission of USUV and WNV. An. plumbeus, however, was tested competent for WNV, and Ae. geniculatus for CHIKV and WNV [35,36].

For USUV and WNV, the entanglement of mosquito populations with avian populations is necessary for sustaining the enzootic cycle. Recent years have shown a sharp increase in WNV cases [103]. Although serological and molecular screening is regularly carried out in human [113,114] and avian populations $[39,87,115]$, the screening of mosquito populations is less systematic. Also, WNV antibodies are more prevalent in migratory birds, while USUV are more prevalent in resident birds [115]. USUV was more commonly found in mosquitoes than WNV [115].

Epizootics of WNV are episodic [98]; after the first emergence of WNV in France in 1962 [98], the virus was only detected again in the 2000s [116]. Outbreaks were noted from 2004 to 2018 in mainland France [101,103,117], and in 2018 in Germany [102]. The circulation of USUV was suspected in European birds in 2000-2005 [85,118]. USUV emerged in Germany in 2011 [59], and then in France in 2015 [119]. In 2016, an epizootic has globally affected France, Belgium, Germany and The Netherlands [84]. The species involved in these outbreaks were probably members of the genus Culex (e.g., Cx. pipiens s.l.) [51,52].

These recent episodes recall our knowledge gaps on the vector competence of native and invasive species such as Ae. vexans, Ae. japonicus and other Aedes species for ZIKV, CHIKV and DENV; An. plumbeus, Ae. geniculatus, Cs. annulata, and Cx. torrentium for USUV and WNV. In the future, attention should be given to ubiquitous species which could be of importance if their vector competence happens to be demonstrated.

Supplementary Materials: The following are available online at http://www.mdpi.com/1999-4915/11/11/1059/s1, Document S1: Search terms.

Author Contributions: Conceptualization and methodology: J.-P.M., H.F., and J.D.; formal analysis, writing—original draft preparation: J.-P.M.; writing—review and editing: J.-P.M., H.F., A.-B.F., F.S., and J.D.; supervision: A.-B.F., H.F., J.D.

Funding: This research received no external funding.

Acknowledgments: The authors thank Matthieu L. Kaltenbach for proof-reading this manuscript.

Conflicts of Interest: The authors declare no conflict of interest.

\section{References}

1. Vasquez, V.; Haddad, E.; Perignon, A.; Jaureguiberry, S.; Brichler, S.; Leparc-Goffart, I.; Caumes, E. Dengue, chikungunya, and Zika virus infections imported to Paris between 2009 and 2016: Characteristics and correlation with outbreaks in the French overseas territories of Guadeloupe and Martinique. Int. J. Infect. Dis. 2018, 72, 34-39. [CrossRef] [PubMed]

2. Wong, N.; Ahmed, A.; Ahmed, O.; Elsanousi, F.; Veater, J.; Osborne, J.; Aarons, E.; Tang, J.W. A series of Zika virus cases imported into the UK 2016: Comparative epidemiological and clinical features. J. Infect. 2017, 74, 616-618. [CrossRef] [PubMed]

3. Wiwanitkit, S.; Wiwanitkit, V. Estimated number of local transmission cases of Zika virus infection imported from Brazil to France. Asian Pac. J. Trop. Med. 2016, 9, 1022. [CrossRef] [PubMed]

4. Delisle, E.; Rousseau, C.; Broche, B.; Leparc-Goffart, I.; L'Ambert, G.; Cochet, A.; Prat, C.; Foulongne, V.; Ferre, J.B.; Catelinois, O.; et al. Chikungunya outbreak in Montpellier, France, september to october 2014. Eurosurveillance 2015, 20, 8-13. [CrossRef] 
5. Succo, T.; Leparc-Goffart, I.; Ferre, J.B.; Roiz, D.; Broche, B.; Maquart, M.; Noel, H.; Catelinois, O.; Entezam, F.; Caire, D.; et al. Autochthonous dengue outbreak in Nîmes, south of France, july to september 2015. Eurosurveillance 2016, 21, 5-11. [CrossRef]

6. Sieg, M.; Schmidt, V.; Ziegler, U.; Keller, M.; Hoper, D.; Heenemann, K.; Ruckner, A.; Nieper, H.; Muluneh, A.; Groschup, M.H.; et al. Outbreak and cocirculation of three different Usutu virus strains in eastern Germany. Vector Borne Zoonotic Dis. 2017, 17, 662-664. [CrossRef]

7. Vazeille, M.; Jeannin, C.; Martin, E.; Schaffner, F.; Failloux, A.B. Chikungunya: A risk for Mediterranean countries? Acta Trop. 2008, 105, 200-202. [CrossRef]

8. Heitmann, A.; Jansen, S.; Lühken, R.; Leggewie, M.; Badusche, M.; Pluskota, B.; Becker, N.; Vapalahti, O.; Schmidt-Chanasit, J.; Tannich, E. Experimental transmission of Zika virus by mosquitoes from central Europe. Eurosurveillance 2017, 22, 4-6. [CrossRef]

9. Ciocchetta, S.; Prow, N.A.; Darbro, J.M.; Frentiu, F.D.; Savino, S.; Montarsi, F.; Capelli, G.; Aaskov, J.G.; Devine, G.J. The new European invader Aedes (Finlaya) koreicus: A potential vector of chikungunya virus. Pathog. Glob. Health 2018, 112, 107-114. [CrossRef]

10. Veronesi, E.; Paslaru, A.; Silaghi, C.; Tobler, K.; Glavinic, U.; Torgerson, P.; Mathis, A. Experimental evaluation of infection, dissemination, and transmission rates for two West Nile virus strains in European Aedes japonicus under a fluctuating temperature regime. Parasitol. Res. 2018, 117, 1925-1932. [CrossRef]

11. Schaffner, F.; Vazeille, M.; Kaufmann, C.; Failloux, A.B.; Mathis, A. Vector competence of Aedes japonicus for chikungunya and dengue viruses. J. Eur. Mosq. Control Assoc. 2011, 29, 141-142.

12. Blagrove, M.S.; Sherlock, K.; Chapman, G.E.; Impoinvil, D.E.; McCall, P.J.; Medlock, J.M.; Lycett, G.; Solomon, T.; Baylis, M. Evaluation of the vector competence of a native UK mosquito Ochlerotatus detritus (Aedes detritus) for dengue, chikungunya and West Nile viruses. Parasit. Vectors 2016, 9, 452. [CrossRef]

13. Talbalaghi, A.; Moutailler, S.; Vazeille, M.; Failloux, A.B. Are Aedes albopictus or other mosquito species from northern Italy competent to sustain new arboviral outbreaks? Med. Vet. Entomol. 2010, 24, 83-87. [CrossRef]

14. Peel, M.C.; Finlayson, B.L.; McMahon, T.A. Updated world map of the Köppen-Geiger climate classification. Hydrol. Earth Syst. Sci. Discuss. 2007, 11, 1633-1644. [CrossRef]

15. Rubel, F.; Brugger, K.; Haslinger, K.; Auer, I. The climate of the European Alps: Shift of very high resolution Köppen-Geiger climate zones 1800-2100. Met. Zeit. 2017, 26, 115-125. [CrossRef]

16. Schaffner, F.; Angel, G.; Geoffroy, B.; Hervy, J.P.; Rhaiem, A.; Brunhes, J. The Mosquitoes of Europe: An Identification and Training Programme; Institut de Recherche pour le Développement: Paris, France; Montpellier, France, 2001.

17. Robert, V.; Günay, F.; Le Goff, G.; Boussès, P.; Sulesco, T.; Khalin, A.; Medlock, J.M.; Kampen, H.; Petrić, D.; Schaffner, F. Distribution chart for Euro-Mediterranean mosquitoes (western Palaearctic region). J. Eur. Mosq. Control Assoc. 2019, 37, 1-28.

18. Moher, D.; Shamseer, L.; Clarke, M.; Ghersi, D.; Liberati, A.; Petticrew, M.; Shekelle, P.; Stewart, L.A.; Group, P.-P. Preferred reporting items for systematic review and meta-analysis protocols (PRISMA-P) 2015 statement. Syst. Rev. 2015, 4, 1. [CrossRef]

19. Boukraa, S.; Dekoninck, W.; Versteirt, V.; Schaffner, F.; Coosemans, M.; Haubruge, E.; Francis, F. Updated checklist of the mosquitoes (Diptera: Culicidae) of Belgium. J. Vector Ecol. 2015, 40, 398-407. [CrossRef]

20. Walther, D.; Kampen, H. The citizen science project 'Mueckenatlas' helps monitor the distribution and spread of invasive mosquito species in Germany. J. Med. Entomol. 2017, 54, 1790-1794. [CrossRef]

21. Medlock, J.M.; Vaux, A.G.C. Aedes (Aedes) geminus Peus (Diptera, Culicidae)—An addition to the british mosquito fauna. Dipt. Dig. 2010,17, 1-6.

22. Matthias Beck, M.G.; Weitzel, T.; Fohlmeister, V.; Kaiser, A.; Amold, A.; Becker, N. Preliminary studies on the mosquito fauna of Luxembourg. Eur. Mosq. Bull. 2003, 14, 21-24.

23. Schaffner, F.; Mathis, A. Spatio-Temporal Diversity of the Mosquito Fauna (Diptera-Culicidae) in Switzerland; Institute of Parsitology, University of Zürich: Zürich, Switzerland, 2013.

24. Verdonschot, P.F.M. Family Culicidae. Available online: http://www.diptera-info.nl/news.php?fam=Culicidae (accessed on 16 January 2016).

25. Becker, N.; Pfitzner, W.P.; Czajka, C.; Kaiser, A.; Weitzel, T. Anopheles (Anopheles) petragnani Del Vecchio 1939-a new mosquito species for Germany. Parasitol. Res. 2016, 115, 2671-2677. [CrossRef] [PubMed]

26. Timmermann, U.; Becker, N. Mosquito-borne West Nile virus (WNV) surveillance in the Upper Rhine Valley, Germany. J. Vector Ecol. 2010, 35, 140-143. [CrossRef] [PubMed] 
27. Andreadis, T.G.; Anderson, J.F.; Vossbrinck, C.R.; Main, A.J. Epidemiology of West Nile virus in Connecticut: A five-year analysis of mosquito data 1999-2003. Vector Borne Zoonotic. Dis. 2004, 4, 360-378. [CrossRef]

28. Hubalek, Z.; Rudolf, I.; Bakonyi, T.; Kazdova, K.; Halouzka, J.; Sebesta, O.; Sikutova, S.; Juricova, Z.; Nowotny, N. Mosquito (Diptera: Culicidae) surveillance for arboviruses in an area endemic for West Nile (lineage Rabensburg) and Tahyna viruses in central Europe. J. Med. Entomol. 2010, 47, 466-472. [CrossRef]

29. Gendernalik, A.; Weger-Lucarelli, J.; Garcia Luna, S.M.; Fauver, J.R.; Ruckert, C.; Murrieta, R.A.; Bergren, N.; Samaras, D.; Nguyen, C.; Kading, R.C.; et al. American Aedes vexans mosquitoes are competent vectors of Zika virus. Am. J. Trop. Med. Hyg. 2017, 96, 1338-1340. [CrossRef]

30. Dibernardo, A.; Turell, M.J.; Lindsay, L.R.; Loomer, C.; Iranpour, M. Vector competence of some mosquito species from Canada for Zika virus. J. Am. Mosq. Control Assoc. 2017, 33, 276-281. [CrossRef]

31. Turell, M.J.; O'Guinn, M.L.; Dohm, D.J.; Jones, J.W. Vector competence of North American mosquitoes (Diptera-Culicidae) for West Nile virus. J. Med. Entomol. 2001, 38, 130-134. [CrossRef]

32. Takken, W.; Knols, B.G.J. Emerging Pests and Vector-Borne Diseases in Europe; Wageningen Academic Publishers: Wageningen, The Netherlands, 2007; Volume 1, p. 499.

33. Anderson, J.F.; Main, A.J.; Armstrong, P.M.; Andreadis, T.G.; Ferrandino, F.J. Arboviruses in North Dakota, 2003-2006. Am. J. Trop. Med. Hyg. 2015, 92, 377-393. [CrossRef]

34. CDC. Mosquito Species in Which West Nile Virus Has Been Detected, United-States, $1999-2016$. Available online: https://www.cdc.gov/westnile/resources/pdfs/MosquitoSpecies1999--2016.pdf (accessed on 21 March 2019).

35. Prudhomme, J.; Fontaine, A.; Lacour, G.; Gantier, J.C.; Diancourt, L.; Velo, E.; Bino, S.; Reiter, P.; Mercier, A. The native European Aedes geniculatus mosquito species can transmit chikungunya virus. Emerg. Microbes Infect. 2019, 8, 962-972. [CrossRef]

36. Vermeil, C.; Lavillaureix, J.; Reeb, E. Survival and transmission of West Nile virus by various arthropods. Bull. Soc. Pathol. Exot. 1960, 53, 300-306.

37. Jansen, S.; Heitmann, A.; Lühken, R.; Jöst, H.; Helms, M.; Vapalahti, O.; Schmidt-Chanasit, J.; Tannich, E. Experimental transmission of Zika virus by Aedes japonicus japonicus from southwestern Germany. Emerg. Microbes Infect. 2018, 7, 192. [CrossRef]

38. Huber, K.; Jansen, S.; Leggewie, M.; Badusche, M.; Schmidt-Chanasit, J.; Becker, N.; Tannich, E.; Becker, S.C. Aedes japonicus japonicus (Diptera: Culicidae) from Germany have vector competence for Japan encephalitis virus but are refractory to infection with West Nile virus. Parasitol. Res. 2014, 113, 3195-3199. [CrossRef] [PubMed]

39. Pietsch, C.; Trawinski, H.; Lubbert, C.; Liebert, U.G. Short communication: West nile fever imported from Austria to Germany. Transbound. Emerg. Dis. 2019, 66, 1033-1036. [CrossRef]

40. Hubalek, Z.; Halouzka, J. West nile fever-a reemerging mosquito-borne viral disease in Europe. Emerg. Infect. Dis. 1999, 5, 643-650. [CrossRef]

41. Balenghien, T.; Vazeille, M.; Grandadam, M.; Schaffner, F.; Zeller, H.; Reiter, P.; Sabatier, P.; Fouque, F.; Bicout, D.J. Vector competence of some French Culex and Aedes mosquitoes for West Nile virus. Vector Borne Zoonotic Dis. 2008, 8, 589-595. [CrossRef]

42. Mancini, G.; Montarsi, F.; Calzolari, M.; Capelli, G.; Dottori, M.; Ravagnan, S.; Lelli, D.; Chiari, M.; Santilli, A.; Quaglia, M.; et al. Mosquito species involved in the circulation of West Nile and Usutu viruses in Italy. Vet. Ital. 2017, 53, 97-110.

43. Goddard, L.B.; Roth, A.E.; Reisen, W.K.; Scott, T.W. Vector competence of California mosquitoes for West Nile virus. Emerg. Infect. Dis. 2002, 8, 1385-1391. [CrossRef]

44. Paupy, C.; Ollomo, B.; Kamgang, B.; Moutailler, S.; Rousset, D.; Demanou, M.; Herve, J.P.; Leroy, E.; Simard, F. Comparative role of Aedes albopictus and Aedes aegypti in the emergence of dengue and chikungunya in Central Africa. Vector Borne Zoonotic Dis. 2010, 10, 259-266. [CrossRef]

45. Lourenco-de-Oliveira, R.; Mousson, L.; Vazeille, M.; Fuchs, S.; Yebakima, A.; Gustave, J.; Girod, R.; Dusfour, I.; Leparc-Goffart, I.; Vanlandingham, D.L.; et al. Chikungunya virus transmission potential by local Aedes mosquitoes in the Americas and Europe. PLoS Negl. Trop. Dis. 2015, 9, e0003780.

46. Jupille, H.; Seixas, G.; Mousson, L.; Sousa, C.A.; Failloux, A.B. Zika virus, a new threat for Europe? Plos Negl. Trop. Dis. 2016, 10, e0004901. [CrossRef] [PubMed] 
47. Puggioli, A.; Bonilauri, P.; Calzolari, M.; Lelli, D.; Carrieri, M.; Urbanelli, S.; Pudar, D.; Bellini, R. Does Aedes albopictus (Diptera: Culicidae) play any role in Usutu virus transmission in northern Italy? Experimental oral infection and field evidences. Acta Trop. 2017, 172, 192-196. [CrossRef] [PubMed]

48. Brustolin, M.; Talavera, S.; Santamaria, C.; Rivas, R.; Pujol, N.; Aranda, C.; Marques, E.; Valle, M.; Verdun, M.; Pages, N.; et al. Culex pipiens and Stegomyia albopicta (=Aedes albopictus) populations as vectors for lineage 1 and 2 West Nile virus in Europe. Med. Vet. Entomol. 2016, 30, 166-173. [CrossRef] [PubMed]

49. Schaffner, F.; Karch, S. Première observation d'Aedes albopictus (Skuse, 1894) en France métropolitaine. Comptes Rendus Acad. Sci. 2000, 323, 373-375. [CrossRef]

50. Balenghien, T.; Vazeille, M.; Reiter, P.; Schaffner, F.; Zeller, H.; Bicout, D.J. Evidence of laboratory vector competence of Culex modestus for West Nile virus. J. Am. Mosq. Control Assoc. 2007, 23, 233-236. [CrossRef]

51. Fros, J.J.; Miesen, P.; Vogels, C.B.; Gaibani, P.; Sambri, V.; Martina, B.E.; Koenraadt, C.J.; van Rij, R.P.; Vlak, J.M.; Takken, W.; et al. Comparative Usutu and West Nile virus transmission potential by local Culex pipiens mosquitoes in north-western Europe. One Health (Amst. Neth.) 2015, 1, 31-36. [CrossRef]

52. Hernandez-Triana, L.M.; de Marco, M.F.; Mansfield, K.L.; Thorne, L.; Lumley, S.; Marston, D.; Fooks, A.A.; Johnson, N. Assessment of vector competence of UK mosquitoes for Usutu virus of African origin. Parasit. Vectors 2018, 11, 381. [CrossRef]

53. Fros, J.J.; Geertsema, C.; Vogels, C.B.; Roosjen, P.P.; Failloux, A.B.; Vlak, J.M.; Koenraadt, C.J.; Takken, W.; Pijlman, G.P. West Nile virus: High transmission rate in north-western European mosquitoes indicates its epidemic potential and warrants increased surveillance. PLoS Negl. Trop. Dis. 2015, 9, e0003956. [CrossRef]

54. Vogels, C.B.F.; Goertz, G.P.; Pijlman, G.P.; Koenraadt, C.J.M. Vector competence of northern and southern European Culex pipiens pipiens mosquitoes for West Nile virus across a gradient of temperatures. Med. Vet. Entomol. 2017, 31, 358-364. [CrossRef]

55. Wagner, S.; Mathis, A.; Schonenberger, A.C.; Becker, S.; Schmidt-Chanasit, J.; Silaghi, C.; Veronesi, E. Vector competence of field populations of the mosquito species Aedes japonicus japonicus and Culex pipiens from Switzerland for two West Nile virus strains. Med. Vet. Entomol. 2018, 32, 121-124. [CrossRef]

56. Leggewie, M.; Badusche, M.; Rudolf, M.; Jansen, S.; Börstler, J.; Krumkamp, R.; Huber, K.; Krüger, A.; Schmidt-Chanasit, J.; Tannich, E.; et al. Culex pipiens and Culex torrentium populations from central Europe are susceptible to West Nile virus infection. One Health (Amst. Neth.) 2016, 2, 88-94. [CrossRef] [PubMed]

57. Eiden, M.; Gil, P.; Ziegler, U.; Rakotoarivony, I.; Marie, A.; Frances, B.; L'Ambert, G.; Simonin, Y.; Foulongne, V.; Groschup, M.H.; et al. Emergence of two Usutu virus lineages in Culex pipiens mosquitoes in the Camargue, France, 2015. Infect. Genet. Evol. 2018, 61, 151-154. [CrossRef] [PubMed]

58. Scheuch, D.E.; Schafer, M.; Eiden, M.; Heym, E.C.; Ziegler, U.; Walther, D.; Schmidt-Chanasit, J.; Keller, M.; Groschup, M.H.; Kampen, H. Detection of Usutu, Sindbis, and Batai viruses in mosquitoes (diptera: Culicidae) collected in Germany, 2011-2016. Viruses 2018, 10, 12. [CrossRef]

59. Jöst, H.; Bialonski, A.; Maus, D.; Sambri, V.; Eiden, M.; Groschup, M.H.; Gunther, S.; Becker, N.; Schmidt-Chanasit, J. Isolation of Usutu virus in Germany. Am. J. Trop. Med. Hyg. 2011, 85, 551-553. [CrossRef]

60. Cadar, D.; Bosch, S.; Jöst, H.; Börstler, J.; Garigliany, M.M.; Becker, N.; Schmidt-Chanasit, J. Putative lineage of novel African Usutu virus, Central Europe. Emerg. Infect. Dis. 2015, 21, 1647-1650. [CrossRef]

61. Vaux, A.G.; Gibson, G.; Hernandez-Triana, L.M.; Cheke, R.A.; McCracken, F.; Jeffries, C.L.; Horton, D.L.; Springate, S.; Johnson, N.; Fooks, A.R.; et al. Enhanced West Nile virus surveillance in the North Kent marshes, UK. Parasit. Vectors 2015, 8, 91. [CrossRef]

62. Amraoui, F.; Atyame-Nten, C.; Vega-Rua, A.; Lourenco-de-Oliveira, R.; Vazeille, M.; Failloux, A.B. Culex mosquitoes are experimentally unable to transmit Zika virus. Eurosurveillance 2016, 21, 2-5. [CrossRef]

63. Camp, J.V.; Bakonyi, T.; Soltesz, Z.; Zechmeister, T.; Nowotny, N. Uranotaenia unguiculata Edwards, 1913 are attracted to sound, feed on amphibians, and are infected with multiple viruses. Parasit. Vectors 2018, 11, 456. [CrossRef]

64. Kemenesi, G.; Dallos, B.; Oldal, M.; Kutas, A.; Foldes, F.; Nemeth, V.; Reiter, P.; Bakonyi, T.; Banyai, K.; Jakab, F. Putative novel lineage of West Nile virus in Uranotaenia unguiculata mosquito, Hungary. Virus Dis. 2014, 25, 500-503. [CrossRef]

65. Pachler, K.; Lebl, K.; Berer, D.; Rudolf, I.; Hubalek, Z.; Nowotny, N. Putative new West Nile virus lineage in Uranotaenia unguiculata mosquitoes, Austria, 2013. Emerg. Infect. Dis. 2014, 20, 2119-2122. [CrossRef] 
66. Robinson, M.C. An epidemic of virus disease in southern province, Tanganyika territory, in 1952-53. I. Clinical features. Trans. Roy. Soc. Trop. Med. Hyg. 1955, 49, 28-32. [CrossRef]

67. Amraoui, F.; Failloux, A.B. Chikungunya: An unexpected emergence in Europe. Curr. Opin. Virol. 2016, 21, 146-150. [CrossRef] [PubMed]

68. Vazeille, M.; Moutailler, S.; Coudrier, D.; Rousseaux, C.; Khun, H.; Huerre, M.; Thiria, J.; Dehecq, J.S.; Fontenille, D.; Schuffenecker, I.; et al. Two chikungunya isolates from the outbreak of la Réunion (Indian ocean) exhibit different patterns of infection in the mosquito, Aedes albopictus. PLOS ONE 2007, 2, e1168. [CrossRef] [PubMed]

69. Tomasello, D.; Schlagenhauf, P. Chikungunya and dengue autochthonous cases in Europe, 2007-2012. Travel Med. Infect. Dis. 2013, 11, 274-284. [CrossRef]

70. Grandadam, M.; Caro, V.; Plumet, S.; Thiberge, J.M.; Souares, Y.; Failloux, A.B.; Tolou, H.J.; Budelot, M.; Cosserat, D.; Leparc-Goffart, I.; et al. Chikungunya virus, southeastern France. Emerg. Infect. Dis. 2011, 17, 910-913. [CrossRef]

71. European Center for Disease Prevention and Control. 2016 Chikungunya Virus Disease; European Center for Disease Prevention and Control: Stockholm, Sweden, 2018.

72. Calba, C.; Guerbois-Galla, M.; Franke, F.; Jeannin, C.; Auzet-Caillaud, M.; Grard, G.; Pigaglio, L.; Decoppet, A.; Weicherding, J.; Savaill, M.C.; et al. Preliminary report of an autochthonous chikungunya outbreak in France, july to september 2017. Eurosurveillance 2017, 22, 5-10. [CrossRef]

73. Venturi, G.; Di Luca, M.; Fortuna, C.; Remoli, M.E.; Riccardo, F.; Severini, F.; Toma, L.; Del Manso, M.; Benedetti, E.; Caporali, M.G.; et al. Detection of a chikungunya outbreak in central Italy, august to september 2017. Eurosurveillance 2017, 22, 17-00646. [CrossRef]

74. European Center for Disease Prevention and Control. Dengue Annual Epidemiological Report 2016; European Center for Disease Prevention and Control: Stockholm, Sweden, 2018.

75. European Center for Disease Prevention and Control. Zika Virus Infection; European Center for Disease Prevention and Control: Stockholm, Sweden, 2018.

76. Bhatt, S.; Gething, P.W.; Brady, O.J.; Messina, J.P.; Farlow, A.W.; Moyes, C.L.; Drake, J.M.; Brownstein, J.S.; Hoen, A.G.; Sankoh, O.; et al. The global distribution and burden of dengue. Nature 2013, 496, 504-507. [CrossRef]

77. La Ruche, G.; Souares, Y.; Armengaud, A.; Peloux-Petiot, F.; Delaunay, P.; Despres, P.; Lenglet, A.; Jourdain, F.; Leparc-Goffart, I.; Charlet, F; et al. First two autochthonous dengue virus infections in metropolitan France, september 2010. Eurosurveillance 2010, 15, 19676.

78. Marchand, E.; Prat, C.; Jeannin, C.; Lafont, E.; Bergmann, T.; Flusin, O.; Rizzi, J.; Roux, N.; Busso, V.; Deniau, J.; et al. Autochthonous case of dengue in France, october 2013. Eurosurveillance 2013, 18, 20661. [CrossRef]

79. Dick, G.W.; Kitchen, S.F.; Haddow, A.J. Zika virus. I. Isolations and serological specificity. Trans. Roy. Soc. Trop. Med. Hyg. 1952, 46, 509-520. [CrossRef]

80. Boyer, S.; Calvez, E.; Chouin-Carneiro, T.; Diallo, D.; Failloux, A.B. An overview of mosquito vectors of Zika virus. Microbes Infect. 2018, 20, 646-660. [CrossRef]

81. Faye, O.; Freire, C.C.; Iamarino, A.; Faye, O.; de Oliveira, J.V.; Diallo, M.; Zanotto, P.M.; Sall, A.A. Molecular evolution of Zika virus during its emergence in the 20(th) century. PLoS Negl. Trop. Dis. 2014, 8, e2636. [CrossRef]

82. Woodall, J. The viruses isolated from arthropods at the East African Virus Research Institute in the 26 years ending december 1963. Proc. E. Afr. Acad 1964, 2, 141-146.

83. Weissenbock, H.; Bakonyi, T.; Rossi, G.; Mani, P.; Nowotny, N. Usutu virus, Italy, 1996. Emerg. Infect. Dis. 2013, 19, 274-277. [CrossRef]

84. Cadar, D.; Lühken, R.; van der Jeugd, H.; Garigliany, M.; Ziegler, U.; Keller, M.; Lahoreau, J.; Lachmann, L.; Becker, N.; Kik, M.; et al. Widespread activity of multiple lineages of Usutu virus, western Europe, 2016. Eurosurveillance 2017, 22, 11-17. [CrossRef]

85. Buckley, A.; Dawson, A.; Moss, S.R.; Hinsley, S.A.; Bellamy, P.E.; Gould, E.A. Serological evidence of West Nile virus, Usutu virus and Sindbis virus infection of birds in the UK. J. Gen. Virol. 2003, 84, 2807-2817. [CrossRef]

86. Garigliany, M.M.; Marlier, D.; Tenner-Racz, K.; Eiden, M.; Cassart, D.; Gandar, F.; Beer, M.; Schmidt-Chanasit, J.; Desmecht, D. Detection of Usutu virus in a bullfinch (Pyrrhula pyrrhula) and a great spotted woodpecker (Dendrocopos major) in north-west Europe. Vet. J. 2014, 199, 191-193. [CrossRef] 
87. Lim, S.M.; Geervliet, M.; Verhagen, J.H.; Muskens, G.; Majoor, F.A.; Osterhaus, A.; Martina, B.E.E. Serologic evidence of West Nile virus and Usutu virus infections in Eurasian coots in the Netherlands. Zoonoses Public Health 2018, 65, 96-102. [CrossRef]

88. Ziegler, U.; Jöst, H.; Muller, K.; Fischer, D.; Rinder, M.; Tietze, D.T.; Danner, K.J.; Becker, N.; Skuballa, J.; Hamann, H.P.; et al. Epidemic spread of Usutu virus in southwest Germany in 2011 to 2013 and monitoring of wild birds for Usutu and West Nile viruses. Vector Borne Zoonotic Dis. 2015, 15, 481-488. [CrossRef]

89. Buchebner, N.; Zenker, W.; Wenker, C.; Steinmetz, H.W.; Sos, E.; Lussy, H.; Nowotny, N. Low Usutu virus seroprevalence in four zoological gardens in central Europe. BMC Vet. Res. 2013, 9, 153. [CrossRef] [PubMed]

90. Vittecoq, M.; Lecollinet, S.; Jourdain, E.; Thomas, F.; Blanchon, T.; Arnal, A.; Lowenski, S.; Gauthier-Clerc, M. Recent circulation of West Nile virus and potentially other closely related flaviviruses in southern France. Vector Borne Zoonotic Dis. 2013, 13, 610-613. [CrossRef] [PubMed]

91. Nikolay, B.; Diallo, M.; Boye, C.S.; Sall, A.A. Usutu virus in Africa. Vector Borne Zoonotic Dis. 2011, 11, 1417-1423. [CrossRef] [PubMed]

92. Pecorari, M.; Longo, G.; Gennari, W.; Grottola, A.; Sabbatini, A.; Tagliazucchi, S.; Savini, G.; Monaco, F.; Simone, M.; Lelli, R.; et al. First human case of Usutu virus neuroinvasive infection, Italy, august-september 2009. Eurosurveillance 2009, 14, 15-17.

93. Nikolay, B. A review of West Nile and Usutu virus co-circulation in Europe: How much do transmission cycles overlap? Trans. Roy. Soc. Trop. Med. Hyg. 2015, 109, 609-618. [CrossRef]

94. Cle, M.; Salinas, S.; Lecollinet, S.; Beck, C.; Gutierrez, S.; Baldet, T.; Vande Perre, P.; Foulongne, V.; Simonin, Y. Usutu virus: The phantom menace. Méd. Sci.: M/S 2018, 34, 709-716.

95. Camp, J.V.; Kolodziejek, J.; Nowotny, N. Targeted surveillance reveals native and invasive mosquito species infected with Usutu virus. Parasit. Vectors 2019, 12, 46. [CrossRef]

96. Smithburn, K.C.; Hughes, T.P.; Burke, A.W.; Paul, J.H. A neurotropic virus isolated from the blood of a native of Uganda. Am. J. Trop. Med. Hyg. 1940, 1, 471-492. [CrossRef]

97. Rudolf, I.; Betasova, L.; Blazejova, H.; Venclikova, K.; Strakova, P.; Sebesta, O.; Mendel, J.; Bakonyi, T.; Schaffner, F.; Nowotny, N.; et al. West Nile virus in overwintering mosquitoes, central Europe. Parasit. Vectors 2017, 10, 452. [CrossRef]

98. Murgue, B.; Murri, S.; Triki, H.; Deubel, V.; Zeller, H.G. West Nile in the Mediterranean basin: 1950-2000. In West Nile Virus: Detection, Surveillance, and Control; White, D.J., Morse, D.L., Eds.; New-York Academy of Sciences: New York, NY, USA, 2001; pp. 117-126.

99. Balenghien, T.; Fouque, F.; Sabatier, P.; Bicout, D.J. Horse-, bird-, and human-seeking behavior and seasonal abundance of mosquitoes in a West Nile virus focus of southern France. J. Med. Entomol. 2006, 43, 936-946. [CrossRef]

100. Van Den Bossche, D.; Cnops, L.; Meersman, K.; Domingo, C.; van Gompel, A.; van Esbroeck, M. Chikungunya virus and West Nile virus infections imported into Belgium, 2007-2012. Epidemiol. Infect. 2015, 143, 2227-2236. [CrossRef]

101. Bahuon, C.; Marcillaud-Pitel, C.; Bournez, L.; Leblond, A.; Beck, C.; Hars, J.; Leparc-Goffart, I.; L'Ambert, G.; Paty, M.C.; Cavalerie, L.; et al. West Nile virus epizootics in the Camargue (France) in 2015 and reinforcement of surveillance and control networks. Rev. Sci. Tech. Off. Int. Epizoot. 2016, 35, 811-824. [CrossRef]

102. Ziegler, U.; Lühken, R.; Keller, M.; Cadar, D.; van der Grinten, E.; Michel, F.; Albrecht, K.; Eiden, M.; Rinder, M.; Lachmann, L.; et al. West Nile virus epizootic in Germany, 2018. Antivir. Res. 2019, 162, $39-43$. [CrossRef]

103. European Center for Disease Prevention and Control. Weekly Updates: 2018 West Nile Fever Transmission Season. Available online: https://www.ecdc.europa.eu/en/news-events/epidemiological-update-west-nilevirus-transmission-season-europe-2018 (accessed on 1 February 2019).

104. Vogels, C.B.; Goertz, G.P.; Pijlman, G.P.; Koenraadt, C.J. Vector competence of European mosquitoes for West Nile virus. Emerg. Microbes Infect. 2017, 6, e96. [CrossRef]

105. Diallo, M.; Thonnon, J.; Traore-Lamizana, M.; Fontenille, D. Vectors of chikungunya virus in Senegal: Current data and transmission cycles. Am. J. Trop. Med. Hyg. 1999, 60, 281-286. [CrossRef]

106. Di Luca, M.; Severini, F.; Toma, L.; Boccolini, D.; Romi, R.; Remoli, M.E.; Sabbatucci, M.; Rizzo, C.; Venturi, G.; Rezza, G.; et al. Experimental studies of susceptibility of Italian Aedes albopictus to Zika virus. Eurosurveillance 2016, 21, 6-9. [CrossRef] 
107. Gutierrez-Lopez, R.; Bialosuknia, S.M.; Ciota, A.T.; Montalvo, T.; Martinez-de la Puente, J.; Gangoso, L.; Figuerola, J.; Kramer, L.D. Vector competence of Aedes caspius and Ae. albopictus mosquitoes for Zika virus, Spain. Emerg. Infect. Dis. 2019, 25, 346-348. [CrossRef]

108. European Center for Disease Prevention and Control. Aedes albopictus-Current Known Distribution: June 2018. Available online: https://ecdc.europa.eu/en/publications-data/aedes-albopictus-current-knowndistribution-june-2018 (accessed on 22 March 2019).

109. Koban, M.B.; Kampen, H.; Scheuch, D.E.; Frueh, L.; Kuhlisch, C.; Janssen, N.; Steidle, J.L.M.; Schaub, G.A.; Werner, D. The Asian bush mosquito Aedes japonicus japonicus (Diptera: Culicidae) in Europe, 17 years after its first detection, with a focus on monitoring methods. Parasit. Vectors 2019, 12, 109. [CrossRef]

110. European Center for Disease Prevention and Control. Aedes japonicus-Current Known Distribution: June 2018. Available online: https://ecdc.europa.eu/en/publications-data/aedes-japonicus-current-knowndistribution-june-2018 (accessed on 22 March 2019).

111. European Center for Disease Prevention and Control. Aedes koreicus_Current Known Distribution: May 2018. Available online: https://ecdc.europa.eu/en/publications-data/aedes-koreicus-current-known-distributionmay-2018 (accessed on 22 March 2019).

112. Dekoninck, W.; Hendrickx, F.; Vasn Bortel, W.; Versteirt, V.; Coosemans, M.; Damiens, D.; Hance, T.; de Clercq, E.M.; Hendrickx, G.; Schaffner, F.; et al. Human-induced expanded distribution of Anopheles plumbeus, experimental vector of West Nile virus and a potential vector of human malaria in Belgium. J. Med. Entomol. 2011, 48, 924-928. [CrossRef]

113. Rabel, P.O.; Planitzer, C.B.; Farcet, M.R.; Orlinger, K.K.; Ilk, R.; Barrett, P.N.; Kreil, T.R. Increasing West Nile virus antibody titres in central European plasma donors from 2006 to 2010. Eurosurveillance 2011, 16, 19812. [CrossRef]

114. Linke, S.; Muehlen, M.; Niedrig, M.; Ellerbrok, H.; Kaiser, A.; Fiedler, W.; Sonnenberg, K.; Alpers, K.; Stark, K.; Pauli, G. Assessing the exposure of German and Austrian bird ringers to West Nile virus (Flavivirus) and evaluating their potential risk of infection. J. Ornithol. 2008, 149, 271-275. [CrossRef]

115. Michel, F.; Fischer, D.; Eiden, M.; Fast, C.; Reuschel, M.; Muller, K.; Rinder, M.; Urbaniak, S.; Brandes, F.; Schwehn, R.; et al. West Nile virus and Usutu virus monitoring of wild birds in Germany. Int. J. Environ. Res. Public Health 2018, 15, 16. [CrossRef] [PubMed]

116. Murgue, B.; Murri, S.; Zientara, S.; Durand, B.; Durand, J.P.; Zeller, H. West Nile outbreak in horses in southern France, 2000: The return after 35 years. Emerg. Infect. Dis. 2001, 7, 692-696. [CrossRef] [PubMed]

117. Del Giudice, P.; Schuffenecker, I.; Vandenbos, F.; Counillon, E.; Zellet, H. Human West Nile virus, France. Emerg. Infect. Dis. 2004, 10, 1885-1886. [CrossRef] [PubMed]

118. Buckley, A.; Dawson, A.; Gould, E.A. Detection of seroconversion to West Nile virus, Usutu virus and Sindbis virus in UK sentinel chickens. Virol. J. 2006, 3, 71. [CrossRef] [PubMed]

119. Lecollinet, S.; Blanchard, Y.; Manson, C.; Lowenski, S.; Laloy, E.; Quenault, H.; Touzain, F.; Lucas, P.; Eraud, C.; Bahuon, C.; et al. Dual emergence of Usutu virus in common blackbirds, eastern France, 2015. Emerg. Infect. Dis. 2016, 22, 2225. [CrossRef]

(C) 2019 by the authors. Licensee MDPI, Basel, Switzerland. This article is an open access article distributed under the terms and conditions of the Creative Commons Attribution (CC BY) license (http://creativecommons.org/licenses/by/4.0/). 